Beryllium

Boron

Titanium

Vanadium

Chromium

Manganese

Iron

Cobalt

Nickel

Copper
Zinc

Strontium

Zirconium

Molybdenum

Tin

Barium

Lead

Uranium (stream sediment)

Uranium (water)

The maps are available for inspection at the Geochemical Division by appointment through the Chief Geochemist.

Institute of Geological Sciences

S. H. U. BOWIE

Geochemical Division

64-78 Grays Inn Road

London WC1X 8NG

Tel: 01-242 4531

31 st August 1972

\title{
A Mediterranean catastrophe
}

SIR,-Most geologists develop early in their training a healthy scepticism towards theories involving catastrophe. A current hypothesis invokes a violent and almost instantaneous flooding of a desiccated low-lying Mediterranean basin with oceanic waters at the beginning of Pliocene time. Properly, this theory has become the subject of fierce controversy.

It was first, I believe, clearly stated by Ruggieri $(1962,1967)$ who claimed that the whole Mediterranean became landlocked towards the close of Miocene time, and dried out to give rise to the evaporites which form the Gessoso-Solfifera Formation in Italy and similar deposits elsewhere.

In Sicily, the Miocene Gessoso-Solffera is overlain by the Trubi Marls of Pliocene age and these marls contain planktonic foraminifera and psychrospheric ostracods which indicate cold, deep water directly open to the ocean (Benson \& Sylvester-Bradley, 1971).

Ruggieri's hypothesis, fantastic as it seems, has been greatly strengthened by the findings made during the Glomar-Challenger cruise in the Mediterranean. Cores have revealed thick Miocene evaporites in all the deep basins, east and west. These are overlain by oceanic sediments closely comparable to the Trubi Marls. And the evaporites in the Red Sea seem to tell the same story.

Two parts of Ruggieri's hypothesis are particularly controversial and these can be explained in other ways. The first alternative claims that the so-called evaporites do not indicate desiccation, but were deposited in submarine conditions. The second claims that the Pliocene transgression was not, by any manner of means, instantaneous, the marine deposits overlying the evaporites being of different ages in different parts of the Mediterranean.

The issues are clear-cut but lack documentation. May I please appeal to those who know the sections to place them on record. It should be perfectly possible to mount an impartial investigation which would resolve the issue. This is especially important in Italy, where directly contrary claims have been made. If the catastrophists are right:

1. The upper levels of the Gessoso-Solfifera should yield a shallow-water euryhaline fauna characterized by such species as the ostracod Cyprideis pannonica.

2. The lowest beds of the marine cover should everywhere yield fossils of the same zone.

If the catastrophists are wrong, the evaporites should contain a marine fauna, and the overlying beds should vary in age and facies. 


\section{References}

Benson, R. H. \& Sylvester-Bradley, P. C. 1971. Deep-sea ostracodes and the transformation of ocean to sea in the Tethys. Bull. Centre Rech. Pau-S.N.P.A. suppl. 5, 53-91.

Ruggieri, G. 1962. La serie marina pliocenica e quaternaria della Romagna. Pub. della Camera di Commercio di Forli, 1-77.

1967. The Miocene and later evolution of the Mediterranean Sea. Syst. Ass. Publ. 7, 283-90.

Department of Geology

P. C. SYLVESTER-BRADLEY

Bennett Building

The University

Leicester

6th September 1972

\section{Myrmekites of exsolution and replacement origins- a discussion}

SIR,-In his study of myrmekite Dr Ashworth (1972) has presented an excellent account of his ideas on the genesis of this intergrowth, and his paper will undoubtedly rank as one of the best on this topic. An important part of his work covers material similar to that described by Phillips, Ransom \& Vernon (1972) dealing with an association between myrmekite, muscovite and relict potash feldspar in retrograde metamorphic rocks from Broken Hill, New South Wales. Because both papers were published at the same time, without any cross reference, I would like to extend our discussion here to include some of Ashworth's original presentation. In addition, I would like to take this opportunity to comment on some other aspects of Ashworth's paper.

Ashworth said that myrmekite in the migmatites of the Huntly-Portsoy area had two distinct modes of occurrence (his types I and II). The type I (or 'normal') myrmekites are attributable to exsolution-dominated processes and formed ${ }^{\circ} . .$. as temperatures declined from their climactic values during regional metamorphism of the rocks'. The type II myrmekites do not result from simple exsolution but depend also on an essential metasomatic contribution, and '... reaction occurred early in the cooling history of the rock'. He appeared to suggest that both forms develop under retrograde metamorphic conditions and he seemed to find no significant time difference between the formation of each of his myrmekite types. Work on the Broken Hill gneisses has suggested that perhaps three generations of myrmekite exist: one developed by metasomatic replacement processes taking place during the approach of the culmination of prograde metamorphism (Phillips \& Ransom, 1970), another possibly formed by exsolution effective shortly after the main prograde metamorphism (Ashworth's type I?), and the third (in which muscovite is associated with the myrmekite, Phillips et al., 1972) related to a later retrograde metamorphic event (Ashworth's type II ?). Shelley (1970, p. 677) also mentioned '... myrmekite showing more than one stage of development ...' so it is possible that these concepts may be applicable to the rocks studied by Ashworth.

Ashworth believed that his type II myrmekite, associated with a muscovite-quartz intergrowth, completely pseudomorphs potash feldspar. Phillips et al. (1972, Figs 3 \& 4) noted similar occurrences, but we do not find any quartz intergrown with the muscovite. Further, after another examination of our slides, I find it difficult to define exactly the limits of any pseudomorph (as Ashworth does when he places a large muscovite grain across a pseudomorph boundary, his Fig. 1b), and I cannot be sure, because of the limits of the two-dimensional cut of a thin-section, that any given pseudomorph represents a completely replaced potash feldspar. 